ORIGINAL RESEARCH PAPER

\title{
APPLICATION OF RESPONSE SURFACE METHODOLOGY TO OPTIMIZE SOME FERMENTATION AND FORMULATION CONDITIONS OF WHEAT DOUGH FORTIFIED WITH MALT CULMS FLOUR
}

\author{
ANDREI I. SIMION ${ }^{1}$, CRISTINA G. GRIGORAȘ ${ }^{1 *}$, LIDIA FAVIER $^{2 * *}$, GABRIELA MUNTIANU $^{1}$, \\ LUCIAN GAVRILA ${ }^{1}$ \\ 1 "Vasile Alecsandri" University of Bacău, Faculty of Engineering, \\ Department of Food and Chemical Engineering, 157 Calea Mărăşești, 600115 Bacău, Romania \\ ${ }^{2}$ Univ Rennes, Ecole Nationale Supérieure de Chimie de Rennes; CNRS, UMR 6226; 11 Allée de Beaulieu, CS \\ 50837, 35708 Rennes Cedex 7, France \\ Corresponding author: * $\underline{\text { cristina.grigoras@ub.ro, }{ }^{* *} \text { lidia.favier@ensc-rennes.fr }}$
}

Received on $9^{\text {th }}$ May 2019

Revised on $31^{\text {st }}$ October 2019

\begin{abstract}
The effect of four different parameters namely the malt culms flour addition, the salt percentage, the fermentation period and temperature on two quality indicators of bread dough: deformation and total titratable acidity was analyzed and interpreted by response surface methodology. The optimization of the imposed experimental conditions led to a quality dough characterized by $23.86 \%$ deformation and $2.64 \mathrm{~mL} \mathrm{NaOH} 0.1 \mathrm{~N}$ total titratable acidity. These values were obtained using wheat flour with addition of $7.4 \%$ malt culms flour and salt in a quantity of $2.25 \%$ compared to the total amount of flour. The dough was subjected to fermentation for 43 minutes at a temperature of $36^{\circ} \mathrm{C}$. The bread obtained after baking presented similar organoleptic characteristics to those registered for the white bread its increased nutrient intake recommending its consumption for an equilibrated diet.
\end{abstract}

Keywords: dough deformation, fermentation, malt culms flour, Response Surface Regression, total titratable acidity

\section{Introduction}

The term dietary fibre was used for the first time in 1953 by Eben Hipsley in order to describe those compounds that are part of the plant cell walls and include celluloses, hemicelluloses and lignin, which are known as non-digestible by the human body (Hipsley, 1953). Various other definitions based on physical and chemical characteristics (Arrigoni et al., 1984; Kaczmarczyk et al., 2012) but also on their physiological effects (McCleary, 2007) were developed until now. From

https://doi.org/10.35219/foodtechnology.2019.2.06 
2009, at the suggestion of Nutrition and Dietary Fibre Committee, Codex Alimentarius Commission defined dietary fibres as polymeric carbohydrates (with more than ten monomer units) that cannot be hydrolyzed by endogenous enzymes existing in human small intestine. Codex Commission stipulates that these polymers can be procured directly from foods in which they can be naturally found or indirectly from natural sources by physical, enzymatic and chemical methods (Wenzel de Menezes et al., 2011).

Dietary fibre consumption has many beneficial effects on human body. Along to their indisputable influence on digestion process, they have been associated with reduced risk of gut (Makki et al., 2018), type 2 diabetes (Davison and Temple, 2018; Ewers et al., 2019), cardiovascular diseases (Dieter and Tuttle, 2017; McRae, 2017), ovaries cancer (Xu et al., 2018), breast cancer (Rohan et al., 1992), colon cancer (Chen and Vietta, 2018; Kaczmarczyk et al., 2012) etc. Dietary fibre are abundant in fruits (López-Vargas et al., 2013; Martínez et al., 2012; Pastell et al., 2019; Shanmugam et al., 2017), vegetables (O'Shea et al., 2012), cereals (Hollmann et al., 2013; Benitez et al., 2018; Dhang and Vasanthan, 2019) and in their by-products. One of these by-products is represented by malt culms, which result from malting process and are characterized by a high nutritive value conferred by the rich content of vitamins, hordein, candicine, betaine, purinic bases, nucleotide and allantoine (Banu et al., 2000).

Dietary fibres intake in human nutrition can be increased by incorporating them in foods such as vegetal cheese (Artiga-Artigas et al., 2017; Montesinos-Herrero et al., 2006; Noronha et al., 2007), fruit fillings (Cropotova, 2015) cakes or bread (Jeddou et al., 2017; Segundo et al., 2017; Simion et al., 2015; Vasantha Rupasinghe et al., 2008). In this last particular case, the fermentation involved in dough preparation has the highest influence on product quality. The yeast leads to alcoholic fermentation with carbon dioxide release, which is responsible of dough loosening. Lactic acid bacteria growth takes place insuring the optimum $p \mathrm{H}$ for yeast development (Ktenioudaki et al., 2009; Soleimani Pour-Damanab et al., 2011). The enzymatic reactions conduct to fermentable sugars and aminoacids useful to yeast and bacteria, while the chemical reactions lead among others to the formation of flavour substances, to gluten complex partial degradation, to changes in dough physical properties, to dough mechanical deformation by carbon dioxide bubles obtained by fermentation and to acidity modifications (Jayaram et al., 2013).

Dough fermentation process is affected by the employed ingredients but also by the used time interval and temperature (Bajd and Serša, 2011). These parameters have an impact on the intensity of enzymatic reactions, on microbiological, physical, chemical, biochemical and colloidal processes and on dough properties. Fermentation takes place optimally at temperatures between 28 and $32{ }^{\circ} \mathrm{C}$ when the flour employed is of high quality. In this case, enzymatic and fermentative processes are accelerated without degrading dough properties.

The moment when fermentation is finalized can be known by following specific indicators. One of these factors is dough deformation which is due especially to the 
important amount of gazes formed. Another parameter able to designate the optimal fermentation is the dough total titratable acidity.

In this context and, since to the best of our knowledge, there are no reports on the use of malt culms flour in bread production, our work was aimed to study its influence on dough quality in order to insure an amplified intake of nutrients necessary for yeast development and for obtaining a product with high fibre amount.

To this purpose, an experimental program was established. The effect of four different parameters namely the malt culms flour percentage, the salt percentage, the fermentation temperature and its time extension on two of the most important dough quality (deformation and total titratable acidity) were followed.

The Response Surface Methodology, an assembly of mathematical and statistical techniques (Madi-Azegagh et al., 2018; Popa et al., 2015a; Popa et al., 2015b; Simion et al., 2017), was employed to analyze the obtained experimental data in order to establish mathematical models able to allow the determination of optimal values for the studied parameters. The obtained dough was baked and the porosity, resilience and total titratable acidity of the resulting bread were analyzed.

\section{Materials and methods}

\section{Dough ingredients}

The wheat white flour, provided by a local producer (Pambac Bacau, Romania) and used for dough preparation, had the following characteristics: moisture content of $14 \%(\mathrm{w} / \mathrm{w})$, total titratable acidity of $2.2 \mathrm{~mL} \mathrm{NaOH} 0.1 \mathrm{~N}$, wet gluten content of $26 \%(\mathrm{w} / \mathrm{w})$, gluten deformation index of $18 \%(\mathrm{w} / \mathrm{w})$ and ash content of $0.48 \%$ (dry basis).

Malt culms flour was obtained by malt culms milling in a Sadkiewicz WZ-2 laboratory scale mill. Chemical composition of the malt culms flour in presented in Table 1, and was established based on AACCI methods (2000) 44-19.01 (water content), 32-45.01 (fibres content), 08.01-01 (ash content), 80-50.01 (sugars content), 32-40.01 (starch content) and ICC standard no. 105/2 (2003) (proteins content).

Table 1. Proximal chemical composition of malt culms flour used in this work

\begin{tabular}{cccc}
\hline Constituent & Amount, \% & Constituent & Amount, \% \\
\hline Water & 8.80 & Ash & 7.20 \\
Proteins & 30.80 & Sugars & 2.90 \\
Fibres & 16.33 & Starch & 26.70 \\
\hline
\end{tabular}

Iodized salt $(99 \%$ sodium chloride $(\mathrm{w} / \mathrm{w})$ and maximum $0.5 \%$ moisture content (w/w)) was produced by Comax M\&M Romanian company.

Yeast (provided by Rompak - Romania) with 70\% moisture had an amount of 55\% proteins (reported on dry basis) according to producer data. 


\section{Farinograph test}

Farinograph test was performed on a Brabender Farinograph ${ }^{\circledR}-\mathrm{E}$ (Brabender GmbH \& Co. KG, Germany) following the indications of ISO 5530-1 (2013) procedure.

\section{Reagents}

Ethanol and sodium hydroxide were purchased from Redox Lab - Bucharest (Romania). Double distilled water used for solutions preparation was procured from Chemical Company Iasi (Romania).

\section{Dough preparation}

Dough was prepared based on the experimental program detailed in Table 2 and Table 3. The added water volume was of $45 \mathrm{~mL}$ for $100 \mathrm{~g}$ of flour. The final blend was kneaded for 10 minutes.

\section{Dough extensograph test}

Extensograph test was carried out with a Brabender Extensograph ${ }^{\circledR}$-E (Brabender GmbH \& Co. KG, Germany) in accordance to ISO 5530-2 method (2013).

\section{Dough deformation analysis}

Dough deformation analysis was carried out based on the method described by Auerman (1964) and expressed in percentage.

\section{Dough baking}

In order to establish the impact of the studied parameters on bread quality $500 \mathrm{~g}$ of dough obtained in the optimal experimental conditions and $500 \mathrm{~g}$ of dough without malt culms flour addition were divided in 5 portions of $100 \mathrm{~g}$ each and baked at $180{ }^{\circ} \mathrm{C}$ for 30 minutes.

\section{Bread analysis}

Bread loaves were evaluated $1 \mathrm{~h}$ after baking. The specific bulk volume was determined according to AACCI 10-05.01 (2000) standard method. The crumb porosity and resilience were established following the procedures described by Canja et al. (2015).

\section{Dough and bread total titratable acidity (TTA) analysis}

TTA was determined at the end of the fermentation process and respectively after baking by using AACCI Method 02-31.01 (2000).

\section{Experimental design and statistical analysis}

Experimental design, mathematical modeling, and optimization were performed using Design-Expert 7.0 software. A custom central composite design (CCD) was used to determine the effects and interactions of four different parameters (the percentage of added malt culms flour, $X_{1}$, salt percentage, $\mathrm{X}_{2}$, temperature, $\mathrm{X}_{3}$ and fermentation duration $\mathrm{X}_{4}$ ) on the obtained dough quality. Data were analyzed by the response surface regression (RSREG) procedure to fit the following secondorder polynomial model (equation 1). 


$$
Y=\beta_{0}+\sum_{i=1}^{k} \beta_{i} X_{i}+\sum_{i=1}^{k} \beta_{i i} X_{i}^{2}+\sum_{i=1}^{k} \sum_{j=1}^{k} \beta_{i j} X_{i} X_{j}+e_{0}
$$

Here, $Y$ is the predicted response of dough deformation $\left(Y_{1}\right)$ and the total titratable acidity $\left(\mathrm{Y}_{2}\right) ; X_{i}$ and $X_{j}$ are variables; $\beta_{0}$ is the constant coefficient; and $\beta_{i}$ is the coefficient that determines the influence of parameter $i$ in the response (linear term), $\beta_{i j}$ is the cross-product coefficient and $\beta_{i i}$ is the quadratic coefficient, which refers to the effects of the interaction among independent variables. The multiple regression analysis can be applied to obtain the coefficient, and the equation can be used to predict the response. The coded values of the parameters can be determined from the following equation:

$$
x_{i}=\frac{X_{i}-X_{0}}{\delta X}
$$

In equation $2 X_{0}$ is the real value of the independent variable at the center point, $X_{i}$ is the real value of the independent variable, and $\delta X$ is the step change values between low $(-1)$ and high $(+1)$ levels (Table 2).

Table 2. Experimental ranges and levels of the independent test variables

\begin{tabular}{lcccccc}
\hline \multicolumn{1}{c}{ Variables } & Symbol & Unit & $\begin{array}{c}\text { Low } \\
\text { actual }\end{array}$ & $\begin{array}{c}\text { High } \\
\text { actual }\end{array}$ & $\begin{array}{c}\text { Low } \\
\text { coded }\end{array}$ & $\begin{array}{c}\text { High } \\
\text { coded }\end{array}$ \\
\hline Malt culms flour & $\mathrm{A}$ & $\%$ & 3 & 9 & -1 & 1 \\
$\mathrm{NaCl}$ & $\mathrm{B}$ & $\%$ & 1.50 & 3.00 & -1 & 1 \\
Fermentation duration & $\mathrm{C}$ & $\mathrm{min}$ & 35 & 45 & -1 & 1 \\
Fermentation temperature & $\mathrm{D}$ & ${ }^{\circ} \mathrm{C}$ & 33 & 37 & -1 & 1 \\
\hline
\end{tabular}

In order to check the validity and to avoid generating an optimal point outside the studied range, for each of the four independent variables, two extreme points were entered in the experimental runs, corresponding to the coding variables -2 and 2 . The considered values were: $0 \%$ and $12 \%$ for malt culms flour addition, $0.75 \%$ and $3.75 \%$ for $\mathrm{NaCl}$ amount, $30 \mathrm{~min}$. and $50 \mathrm{~min}$. for fermentation period and $31{ }^{\circ} \mathrm{C}$ and $39^{\circ} \mathrm{C}$ for fermentation temperature.

\section{Results and discussion}

\section{The fitting of models}

A four-factor three level custom central composite design consisting of 31 experimental runs was adopted to optimize the experimental data, including replications at the center point. Table 3 summarizes the complete design matrix that uses four factors as independent variables and the recorded responses. The empirical second order polynomial equations used to describe the mathematical models are expressed in relations 3 and 4.

$Y_{1}=21.80-0.27 A-0.1 B+1.26 C+2.53 D+0.075 A B-0.021 A C-0.55 A D+0.11 B C-$ $0.10 B D-0.60 C D-0.12 A^{2}-0.31 B^{2}-0.17 C^{2}+0.55 D^{2}$ 
$Y_{2}=2.36-0.084 A+0.088 B+0.23 C+0.19 D+0.011 A B-0.036 A C-0.036 A D+0.36 B C+$ $0.053 B D+0.088 C D-0.014 A^{2}-0.07 B^{2}-0.02 C^{2}+3.777 E-003 D^{2}$

where, $Y_{1}$ and $Y_{2}$ represent the dough deformation and the total titratable acidity, respectively. $A, B, C$ and $D$ are the coded values for the four independent variables.

Table 3. Four factors three level custom central composite design (CCD): design matrix, measured and predicted responses

\begin{tabular}{|c|c|c|c|c|c|c|c|c|}
\hline \multirow[b]{2}{*}{ Run } & \multicolumn{4}{|c|}{ Independent variable (uncoded) } & \multicolumn{2}{|c|}{ Measured response } & \multicolumn{2}{|c|}{ Predicted response } \\
\hline & 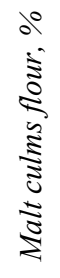 & $\begin{array}{l}d 0 \\
\vec{v} \\
z\end{array}$ & 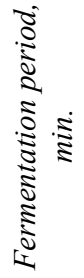 & 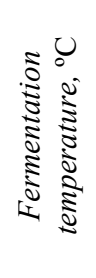 & 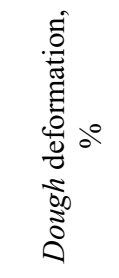 & 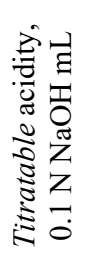 & 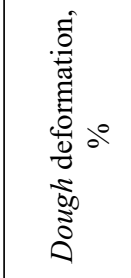 & 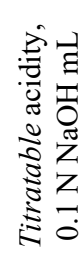 \\
\hline 1 & 3 & 1.5 & 35 & 33 & 20.80 & 2.10 & 20.78 & 2.14 \\
\hline 2 & 6 & 1.5 & 35 & 33 & 25.80 & 2.83 & 24.96 & 2.96 \\
\hline 3 & 3 & 3 & 35 & 33 & 22.30 & 2.38 & 21.80 & 2.36 \\
\hline 4 & 6 & 3 & 35 & 33 & 16.80 & 1.89 & 17.59 & 1.95 \\
\hline 5 & 3 & 1.5 & 45 & 33 & 25.80 & 2.50 & 25.14 & 2.61 \\
\hline 6 & 6 & 1.5 & 45 & 33 & 21.80 & 2.44 & 21.80 & 2.36 \\
\hline 7 & 3 & 3 & 45 & 33 & 20.60 & 2.20 & 21.31 & 2.30 \\
\hline 8 & 6 & 3 & 45 & 33 & 20.60 & 2.00 & 20.75 & 1.91 \\
\hline 9 & 3 & 1.5 & 35 & 37 & 20.50 & 2.40 & 20.35 & 2.26 \\
\hline 10 & 6 & 1.5 & 35 & 37 & 21.80 & 2.41 & 21.80 & 2.36 \\
\hline 11 & 3 & 3 & 35 & 37 & 23.30 & 2.90 & 23.63 & 2.74 \\
\hline 12 & 6 & 3 & 35 & 37 & 21.80 & 2.60 & 21.85 & 2.48 \\
\hline 13 & 3 & 1.5 & 45 & 37 & 27.90 & 2.89 & 29.05 & 2.75 \\
\hline 14 & 6 & 1.5 & 45 & 37 & 25.90 & 3.09 & 25.80 & 3.09 \\
\hline 15 & 3 & 3 & 45 & 37 & 22.00 & 2.37 & 21.80 & 2.36 \\
\hline 16 & 6 & 3 & 45 & 37 & 20.10 & 2.10 & 18.95 & 2.01 \\
\hline 17 & 0 & 2.25 & 40 & 35 & 23.70 & 2.23 & 23.82 & 2.31 \\
\hline 18 & 12 & 2.25 & 40 & 35 & 16.90 & 1.92 & 17.05 & 1.96 \\
\hline 19 & 6 & 0.75 & 40 & 35 & 26.00 & 2.70 & 26.12 & 2.76 \\
\hline 20 & 6 & 3.75 & 40 & 35 & 20.90 & 2.12 & 21.09 & 2.16 \\
\hline 21 & 6 & 2.25 & 30 & 35 & 23.60 & 2.19 & 23.41 & 2.25 \\
\hline 22 & 6 & 2.25 & 50 & 35 & 16.70 & 1.90 & 17.36 & 1.95 \\
\hline 23 & 6 & 2.25 & 40 & 31 & 18.90 & 1.90 & 18.58 & 1.83 \\
\hline 24 & 6 & 2.25 & 40 & 39 & 21.10 & 2.20 & 20.97 & 2.24 \\
\hline 25 & 6 & 2.25 & 40 & 35 & 21.60 & 2.33 & 21.80 & 2.36 \\
\hline 26 & 6 & 2.25 & 40 & 35 & 21.00 & 2.30 & 21.05 & 2.36 \\
\hline 27 & 6 & 2.25 & 40 & 35 & 24.60 & 2.00 & 24.04 & 2.04 \\
\hline 28 & 6 & 2.25 & 40 & 35 & 16.80 & 1.92 & 16.67 & 1.94 \\
\hline 29 & 6 & 2.25 & 40 & 35 & 21.50 & 2.35 & 21.80 & 2.36 \\
\hline 30 & 6 & 2.25 & 40 & 35 & 21.60 & 2.42 & 21.80 & 2.36 \\
\hline 31 & 6 & 2.25 & 40 & 35 & 24.80 & 2.10 & 24.60 & 2.12 \\
\hline
\end{tabular}

The quality of the models was statistically evaluated based on the coefficient of determination $\left(R^{2}\right)$ and on the analysis of variance (ANOVA) (Table 4). 
Table 4. ANOVA results of the response surface quadratic models for dough deformation and total titratable acidity

\begin{tabular}{lccccc}
\hline \multicolumn{1}{c}{ Source } & $\begin{array}{c}\text { Sum of } \\
\text { Squares }\end{array}$ & $\begin{array}{c}\text { Degree of freedom } \\
\text { Square }\end{array}$ & $\begin{array}{c}\text { Mean } \\
\text { F-value }\end{array}$ & p-value \\
\hline Model & 242.2010 & 14 & 17.3000 & 41.9644 & $<0.0001$ \\
Residual & 6.5961 & 16 & 0.4123 & - & - \\
Lack of Fit & 6.1361 & 10 & 0.6136 & 8.0036 & 0.0096 \\
Pure Error & 0.4600 & 6 & 0.0767 & - & - \\
Corected Total & 248.7970 & 30 & - & - & - \\
$R_{\text {squared }}=0.9735$, Adjusted $R_{\text {squared }}=0.9503$, Predicted $R_{\text {squared }}$ & 0.8512 & \\
\multicolumn{7}{c}{$Y_{2}$, Total titratable acidity } & & - \\
\hline Model & 2.9300 & 14 & 0.2093 & 18.0528 & $<0.0001$ \\
Residual & 0.1854 & 16 & 0.0116 & - & - \\
Lack of Fit & 0.1761 & 10 & 0.0176 & 11.2760 & 0.0039 \\
Pure Error & 0.0093 & 6 & 0.0016 & - & - \\
Corected Total & 3.1155 & 30 & - & - & - \\
$R_{\text {squared }}=0.9405$, Adjusted $R_{\text {squared }}=0.8884$, Predicted $R_{\text {squared }}=0.3761$ & \\
\hline
\end{tabular}

The ANOVA results showed that the models were highly significant. This conclusion is sustained by the fact that the $F$-values (41.9644 and 18.0528 for the two responses) are greater than 0.001 . The $p$-values are lower than 0.05 . There are only $0.01 \%$ of the total variation that could not be explained by the model. The lack of fit (with $F$-values of 8.0036 and 11.276 respectively) reveal no statistical meaning as the $p$-values of each are lower than 0.05 ( 0.0096 and 0.0039 , respectively). The registered values for the correlation coefficient $R^{2}$ are 0.9735 for the dough deformation and 0.9405 for the total titratable acidity, and this means that only $1.65 \%$ and $5.95 \%$ of the total variables for responses were not explained by the model. The adjusted $R^{2}$ value also explains the adequacy of the model. Figure 1 shows the measured values versus the predicted responses by the models.

Table 5 shows the ANOVA of the quadratic models coefficients for each response type. Two terms (C and D with $p<0.0001$ ) were found to be statistically significant for dough deformation. The interaction terms $\mathrm{AD}$ and $\mathrm{CD}$ between malt culms flour addition and fermentation temperature respectively fermentation time and fermentation temperature and the quadratic terms $\mathrm{B}^{2}(\mathrm{NaCl}$ percentage $)$ and $\mathrm{D}^{2}$ were highly significant based on a $95 \%$ confidence level $(p<0.05)$.

An intense effect on dough deformation is determined by the time and fermentation temperature. The amount of malt culms flour plays an important role only in combination with the other two parameters.

Also, from Table 5 one can note that only two terms, C and D, with $p<0.0001$ and four terms $\mathrm{A}, \mathrm{B}, \mathrm{CD}, \mathrm{B}^{2}$ with $\mathrm{p}<0.05$ are relevant for dough acidity. 
The sum of squares (SS) for each model component was used to calculate the percentage contributions (PC) of individual terms. For dough stability, the fermentation time (D) showed the highest level of significance with a contribution of $68.57 \%$ as compared to other components. Dough acidity showed the highest level of significance on the fermentation temperature (C) with a contribution of $42.75 \%$.

The malt culms flour addition (A) has more influence on dough stability and affects less its acidity with a contribution of $0.60 \%$ and respectively $4.57 \%$.

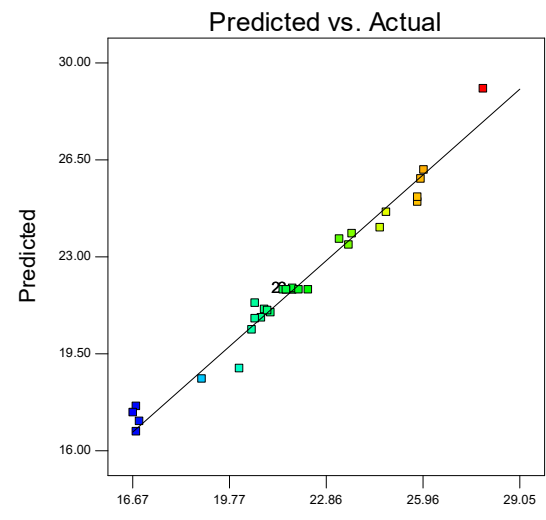

a

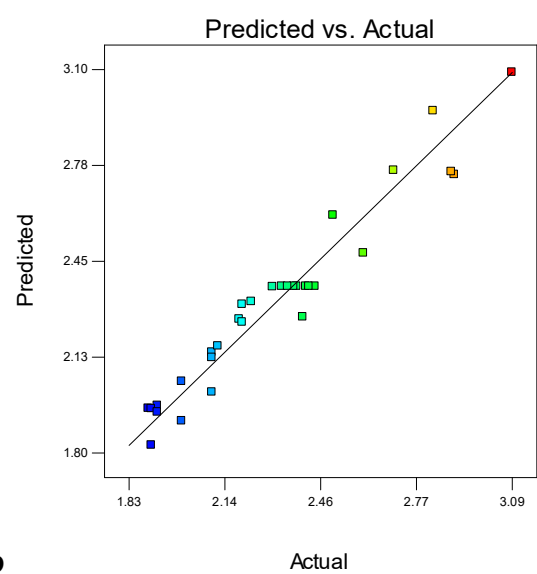

Figure 1. Plots of the actual and predicted values for dough deformation (\%) (a) and the total titratable acidity $(0.1 \mathrm{~N} \mathrm{NaOH} \mathrm{mL})(\mathrm{b})$

Figures 2 and 3 show the influence of single factors while maintaining constant all the others at coded values 0 . Dough stability was almost unchanged with the variation of $\mathrm{NaCl}$ amount. On the other hand, temperature and fermentation time had a negative effect. The malt culms flour addition decreased the dough stability in combination with the fermentation temperature and $\mathrm{NaCl}$ percentage augmentation but in report with fermentation time rise an increase of stability could be observed.

In the case of dough acidity, the augmentation of malt culms flour amount added determined a moderate decrease of acidity the only observed synergic effect being in the rise of acidity, when $\mathrm{NaCl}$ amount is increased.

In the studied conditions dough deformation ranged between $16.7 \%$ and $27.9 \%$, and its TTA between 1.9 and $3.09 \mathrm{~mL}$ of $0.1 \mathrm{M} \mathrm{NaOH}$. The realized experiments have shown that these parameters presented optimum values $(23.86 \%$ deformation, $2.64 \mathrm{~mL} \mathrm{NaOH} 0.1 \mathrm{M}$ ) when using an addition of $7.4 \%$ of malt culms flour. At the same time, it was noticed that the excess dietary fiber inserted in the dough with malt culms flour implied an increase of salt percentage $(2.55 \%$ reported on the total amount of flour). The salt improved the dough quality since this became more elastic and no longer flattened during leavening as happened when the percentage of salt introduced was smaller. 
Table 5. ANOVA results for the coefficient of quadratic model for dough deformation (\%) and dough acidity $(0.1 \mathrm{~N} \mathrm{NaOH} \mathrm{mL})$

\begin{tabular}{|c|c|c|c|c|c|c|c|c|}
\hline \multicolumn{9}{|c|}{$Y_{1}$, Dough deformation } \\
\hline \multicolumn{2}{|l|}{$\begin{array}{l}\text { Standard } \\
\text { deviation }\end{array}$} & \multirow[t]{2}{*}{ Mean } & \multicolumn{2}{|c|}{$\begin{array}{c}\text { Coefficient of } \\
\text { variance, \% }\end{array}$} & \multicolumn{2}{|c|}{$\begin{array}{c}\text { Predicted } \\
\text { residual error } \\
\text { sum of square }\end{array}$} & \multicolumn{2}{|c|}{$\begin{array}{l}\text { Adequate } \\
\text { precision }\end{array}$} \\
\hline \multicolumn{2}{|l|}{0.64} & & \multicolumn{2}{|r|}{2.94} & \multicolumn{2}{|c|}{37.03} & \multicolumn{2}{|c|}{27.720} \\
\hline \multirow[t]{2}{*}{ Factor } & \multirow[t]{2}{*}{ Coefficient } & \multicolumn{2}{|c|}{$\begin{array}{c}95 \% \\
\text { Confidence } \\
\text { interval }\end{array}$} & \multirow{2}{*}{$\frac{5}{5}$} & \multirow{2}{*}{$\underset{\substack{5 \\
\frac{5}{2}}}{2}$} & \multirow{2}{*}{ 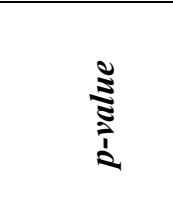 } & \multirow{2}{*}{$\begin{array}{l}5 \\
5 \\
5 \\
5 \\
5 \\
5\end{array}$} & \multirow{2}{*}{ 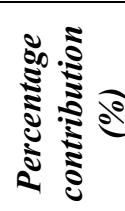 } \\
\hline & & Low & High & & & & & \\
\hline Intercept & 21.79617 & 21.29 & 22.30 & 0.24 & - & - & - & - \\
\hline A & -0.26585 & -0.65 & 0.12 & 0.18 & 2.18 & 0.1590 & 0.90 & 0.60 \\
\hline B & -0.1 & -0.44 & 0.24 & 0.16 & 0.39 & 0.5421 & 0.16 & 0.11 \\
\hline $\mathrm{C}$ & 1.2625 & 0.92 & 1.60 & 0.16 & 61.86 & $<0.0001$ & 25.50 & 17.14 \\
\hline $\mathrm{D}$ & 2.525 & 2.18 & 2.87 & 0.16 & 247.44 & $<0.0001$ & 102.01 & 68.57 \\
\hline $\mathrm{AB}$ & 0.075 & -0.51 & 0.66 & 0.28 & 0.07 & 0.7908 & 0.03 & 0.02 \\
\hline $\mathrm{AC}$ & -0.2125 & -0.80 & 0.38 & 0.28 & 0.58 & 0.4558 & 0.24 & 0.16 \\
\hline $\mathrm{AD}$ & -0.55 & -1.14 & 0.04 & 0.28 & 3.91 & 0.0654 & 1.61 & 1.08 \\
\hline $\mathrm{BC}$ & 0.1125 & -0.23 & 0.45 & 0.16 & 0.49 & 0.4935 & 0.20 & 0.14 \\
\hline $\mathrm{BD}$ & -0.1 & -0.44 & 0.24 & 0.16 & 0.39 & 0.5421 & 0.16 & 0.11 \\
\hline $\mathrm{CD}$ & -0.6 & -0.94 & -0.26 & 0.16 & 13.97 & 0.0018 & 5.76 & 3.87 \\
\hline $\mathrm{A}^{2}$ & -0.12008 & -0.38 & 0.14 & 0.12 & 0.97 & 0.3403 & 0.40 & 0.27 \\
\hline $\mathrm{B}^{2}$ & -0.31093 & -0.57 & -0.05 & 0.12 & 6.42 & 0.0221 & 2.65 & 1.78 \\
\hline $\mathrm{C}^{2}$ & -0.17343 & -0.43 & 0.09 & 0.12 & 2.00 & 0.1768 & 0.82 & 0.55 \\
\hline $\mathrm{D}^{2}$ & 0.551571 & 0.29 & 0.81 & 0.12 & 20.19 & 0.0004 & 8.33 & 5.60 \\
\hline \multicolumn{9}{|c|}{$Y_{2}$, Dough acidity } \\
\hline \multicolumn{2}{|c|}{$\begin{array}{l}\text { Standard } \\
\text { deviation }\end{array}$} & Mean & \multicolumn{2}{|c|}{$\begin{array}{c}\text { Coefficient of } \\
\text { variance, \% }\end{array}$} & \multicolumn{2}{|c|}{$\begin{array}{c}\text { Predicted } \\
\text { residual error } \\
\text { sum of square }\end{array}$} & \multicolumn{2}{|c|}{$\begin{array}{l}\text { Adequate } \\
\text { precision }\end{array}$} \\
\hline 0.11 & & 2.31 & & 4.66 & & 1.94 & & 884 \\
\hline Intercept & 2.364426 & 2.28 & 2.45 & 0.04 & - & - & - & - \\
\hline A & -0.08404 & -0.15 & -0.02 & 0.03 & 7.76 & 0.0132 & 0.09 & 4.57 \\
\hline B & 0.088125 & 0.03 & 0.15 & 0.03 & 10.72 & 0.0048 & 0.12 & 6.31 \\
\hline $\mathrm{C}$ & 0.229375 & 0.17 & 0.29 & 0.03 & 72.61 & $<0.0001$ & 0.84 & 42.75 \\
\hline $\mathrm{D}$ & 0.186875 & 0.13 & 0.24 & 0.03 & 48.20 & $<0.0001$ & 0.56 & 28.38 \\
\hline $\mathrm{AB}$ & 0.010625 & -0.09 & 0.11 & 0.05 & 0.05 & 0.8226 & 0.00 & 0.03 \\
\hline $\mathrm{AC}$ & -0.03563 & -0.13 & 0.06 & 0.05 & 0.58 & 0.4559 & 0.01 & 0.34 \\
\hline $\mathrm{AD}$ & -0.03563 & -0.13 & 0.06 & 0.05 & 0.58 & 0.4559 & 0.01 & 0.34 \\
\hline $\mathrm{BC}$ & 0.035625 & -0.02 & 0.09 & 0.03 & 1.75 & 0.2043 & 0.02 & 1.03 \\
\hline $\mathrm{BD}$ & 0.053125 & 0.00 & 0.11 & 0.03 & 3.90 & 0.0660 & 0.05 & 2.29 \\
\hline $\mathrm{CD}$ & 0.088125 & 0.03 & 0.15 & 0.03 & 10.72 & 0.0048 & 0.12 & 6.31 \\
\hline$A^{2}$ & -0.01385 & -0.06 & 0.03 & 0.02 & 0.46 & 0.5088 & 0.01 & 0.27 \\
\hline $\mathrm{B}^{2}$ & -0.06997 & -0.11 & -0.03 & 0.02 & 11.56 & 0.0037 & 0.13 & 6.80 \\
\hline $\mathrm{C}^{2}$ & -0.01997 & -0.06 & 0.02 & 0.02 & 0.94 & 0.3463 & 0.01 & 0.55 \\
\hline $\mathrm{D}^{2}$ & 0.003777 & -0.04 & 0.05 & 0.02 & 0.03 & 0.8567 & 0.00 & 0.02 \\
\hline
\end{tabular}


The optimal fermentation period was of 43 minutes. The process has led to the best results when the temperature used was set at $36{ }^{\circ} \mathrm{C}$. In this case, the production of carbon dioxide by the yeast was favored fact that conducted to a better dough expansion. However, at higher temperatures, the expansion process diminished due to the combined effect of dough weakening and of carbon dioxide solubility reduction.
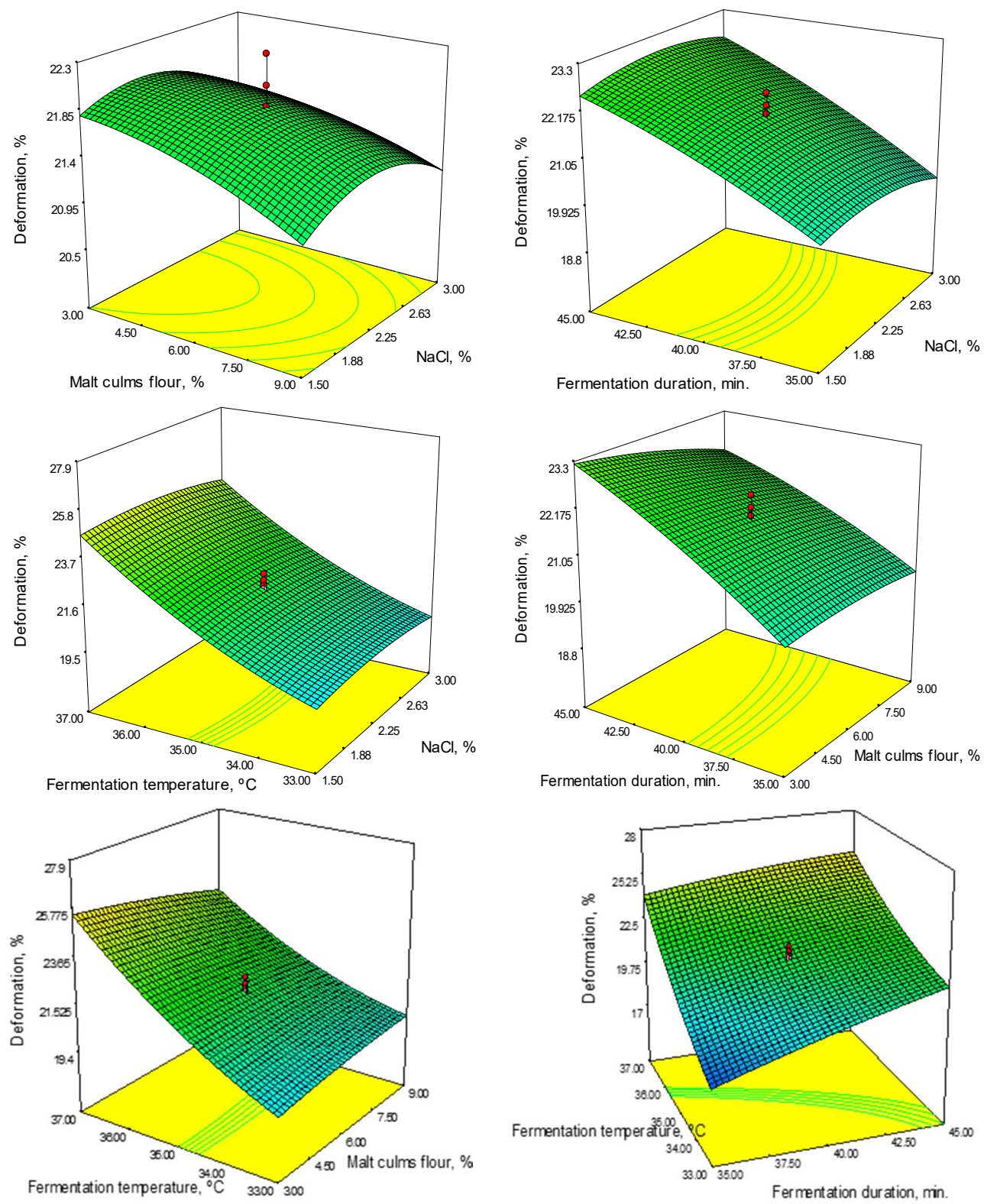

Figure 2. Response surfaces generated when studying the influence of malt culms flour addition, $\mathrm{NaCl}$ percentage, fermentation duration and fermentation temperature on dough deformation 

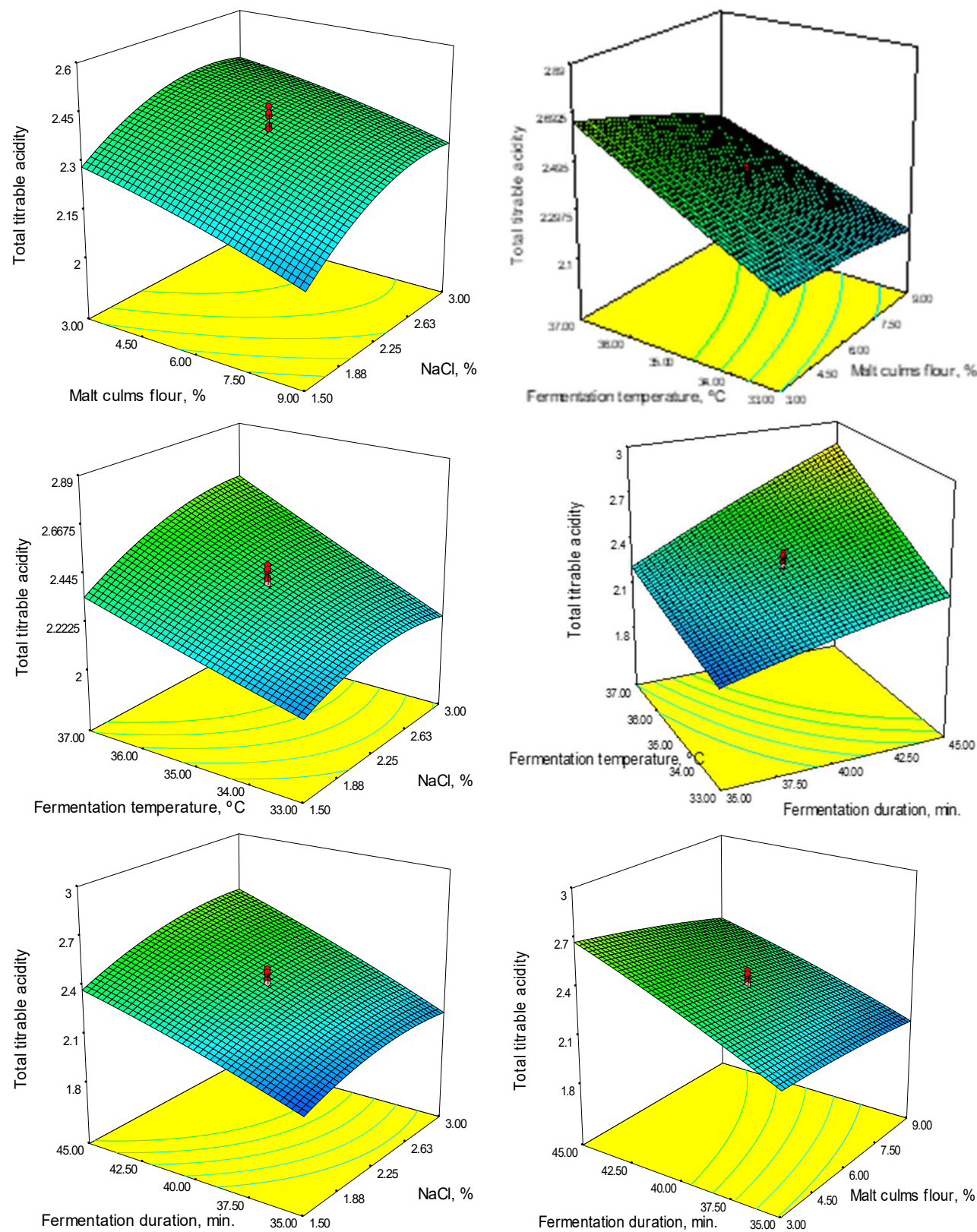

Figure 3. Response surfaces generated when studying the influence of malt culms flour addition, $\mathrm{NaCl}$ percentage, fermentation duration and fermentation temperature on dough acidity

\section{Optimal conditions testing}

The farinograph test of the flour mix with $7.4 \%$ of malt culms flour revealed the following results: $14.3 \%$ flour moisture, $58.1 \%$ water absorption (WA) at 502 
Brabender unit (BU), 58.2\% WA corrected to $500 \mathrm{BU}, 58.7 \%$ WA corrected to $14 \%$ moisture, $2.7 \mathrm{~min}$. dough development, $11.4 \mathrm{~min}$. stability time, $23 \mathrm{BU}$ softening degree (SD) at $10 \mathrm{~min} ., 37 \mathrm{BU}$ SD at $12 \mathrm{~min}$. and 125 Farinograph ${ }^{\circledR}$ quality number (FQN).

The validation of the obtained mathematical models was verified by performing 10 replicates on the optimum determined conditions. According to the statistical analysis, dough deformation was of $23.86 \pm 0.5 \%$, while its TTA ranged between 2.35 and $2.7 \mathrm{~mL} \mathrm{NaOH}$. The differences observed between the experimental results and those raised from the application of mathematical equations were statistically insignificant.

The extensograph test registered at 30/60/90 minutes showed at 56.0\% WA and $2.5 \%$ sodium chloride: $113 / 113 / 117 \mathrm{~cm}^{2}$ energy, 366/502/521 BU resistance to extension, 159/134/138 mm extensibility, 519/655/668 BU maximum resistance to extension.

In order to establish the influence of the studied parameters on bread quality 10 loaves obtained after baking were submitted to a sensorial analysis. The volume, porosity, resilience and TTA for each bread samples were also recorded. The organoleptic aspects revealed no cracks on bread crust and a uniform color. Shell color was golden yellow with a slightly darker shade for bread with malt culms flour addition. The core was well grown, with fine pores, uniform, elastic, unsticky. The aroma was pleasant without foreign smell. The taste was pleasant and slightly salty.

Substitution of a part of wheat flour with malt culms flour leaded to a reduction in loaf volume, which ranged between $340 \mathrm{~g} / \mathrm{cm}^{3}$ and $355 \mathrm{~g} / \mathrm{cm}^{3}$ for simple bread and between $298 \mathrm{~g} / \mathrm{cm}^{3}$ and $320 \mathrm{~g} / \mathrm{cm}^{3}$ for that with fiber addition. The porosity in this case was slightly lower $(68 \pm 0.8 \%$ for fiber-enriched bread compared with $75 \pm$ $1.1 \%$ for that obtained only from white flour). The same observation applies to core resilience. A value of $71 \pm 1.5 \%$ was obtained for the white bread while for the bread with malt culms flour addition the resilience reached only $67 \pm 1.3 \%$. For this bread a slight increase of crumb TTA was noted $(2.64 \mathrm{~mL} \mathrm{NaOH} 0.1 \mathrm{~N})$ compared to that registered for the white bread $(2.4 \mathrm{~mL} \mathrm{NaOH} 0.1 \mathrm{~N})$.

There are no reports on the use of malt culms flour in bread production. However, when other substitutes such as apricot kernel flour (Dhen et al., 2018), fermented chickpea flour (Shrivastava and Chakraborty, 2018), banana peels flour (AlSahlany and Al-Musafer, 2018) or chia flour (Coelho et al., 2015) were employed to partially replace the wheat flour in dough formulation, researches showed similar results for its rheological properties. The mentioned studies reveal also that the end products were enriched in various nutrients including protein, fibers or fat and the bread final has acceptable or even ameliorated physical characteristics.

\section{Conclusions}

The study was aimed firstly at determining the effect of four different parameters (malt culms flour addition, used salt percentage, fermentation temperature and 
fermentation duration) against two of the most important characteristics of dough: deformation and total titratable acidity. The RSM leaded to the optimum values of these parameters $(7.4 \%$ culm malt flour, $2.25 \%$ salt, 43 minutes of fermentation at $36^{\circ} \mathrm{C}$ ) and conducted to mathematical models capable to accurately describe the monitored response functions.

The realised experiments revealed also that the bread enriched in dietary fiber from malt culms flour presented similar characteristics to those of the white bread. The lower values recorded of the studied physicochemical characteristics obtained in the first case are counterbalanced by the possibility of incorporating larger amounts of fiber into the human diet.

\section{References}

AACCI 2000. Approved methods of analysis. $11^{\text {th }}$ ed. St. Paul: AACC International. Method 02-31.01. Method 08-01.01. Method 32-40.01. Method 32-45.01. Method 4419.01. Method 80-50.01.

AACCI Method 10-05.01. 2000. Guidelines for measurement of volume by rapeseed displacement. In: Approved methods of analysis, $11^{\text {th }}$ ed. St. Paul: AACC International

Al-Sahlany, S.T.G., Al-Musafer, A.M.S. 2018. Effect of substitution percentage of banana peels flour in chemical composition, rheological characteristics of wheat flour and the viability of yeast during dough time. Journal of the Saudi Society of Agricultural Sciences, https://doi.org/10.1016/j.jssas.2018.06.005.

Arrigoni, E., Caprez, A., Amado, R., Neukom, H. 1984. Gravimetric method for the determination of insoluble and soluble dietary fibres. Zeitschrift für LebensmittelUntersuchung und-Forschung, 178, 195-198.

Artiga-Artigas, M., Acevedo-Fani, A., Martin-Belloso, O. 2017. Improving the shelf life of low-fat cut cheese using nanoemulsion-based edible coatings containing oregano essential oil and mandarin fiber. Food Control, 76, 1-12.

Auerman, L. E. 1964 Tehnologia panificaţiei, Editura Tehnică, Bucureşti.

Bajd, F., Serša, I. 2011. Continuous monitoring of dough fermentation and bread baking by magnetic resonance microscopy. Magnetic Resonance Imaging, 29, 434-442.

Banu, C., Stoicescu, A., Răsmeriţă, D., Vizireanu, C., Pop, M., Pancu, M., Tofan, I., Verşescu, V. 2000. Tratat de ştiinţa şi tehnologia malţului şi a berii. Vol. I. Editura Agir, Bucureşti.

Benitez, V., Esteban, R. M., Moniz, E., Casado, N., Aguilera, Y., Molla, E. 2018. Breads fortified with wholegrain cereals and seeds as source of antioxidant dietary fibre and other bioactive compounds. Journal of Cereal Science, 82, 113-120.

Canja, C.M., Lupu, M.I., Măzărel, A., Pădureanu, V. 2015. The effect on salt added to the dough rheological properties of that and quality of white bread. Bulletin of the Transilvania University of Brașov. Series II: Forestry. Wood Industry. Agricultural Food Engineering, 8(1), 57-64.

Chen, J., Vietta, L. 2018. Inflammation-modulating effect of butyrate in the prevention of colon cancer by dietary fiber. Clinical Colorectal Cancer, 17(3), e541-544.

Coelho, M.S., Salas-Mellado, M.M. 2015. Effects of substituting chia (Salvia hispanica L.) flour or seeds for wheat flour on the quality of the bread. LWT-Food Science and Technology, 60, 729-736. 
Cropotova, J. 2015. Development and quality assessment of heat-stable fruit fillings containing dietary fibers. Annals of the University Dunarea de Jos of Galati Fascicle VI-Food Technology, 39(2), 38-54.

Davison, K.M., Temple, N.J. 2018. Cereal fiber, fruit fiber, and type 2 diabetes: Explaining the paradox. Journal of Diabetes and its Complications, 32, 240-245.

Dhang, T. T., Vasanthan, T. 2019. Modification of rice bran dietary fiber concentrates using enzyme and extrusion cooking. Food Hydrocolloids, 89, 773-782.

Dhen, N., Rejeb, I. B., Boukhris, H., Damergi, C., Gargouri, M. 2018. Physicochemical and sensory properties of wheat - Apricot kernels composite bread. LWT - Food Science and Technology, 95, 262-267.

Dieter, B.P., Tuttle, K.R. 2017. Dietary strategies for cardiovascular health. Trends in Cardiovascular Medicine, 27, 295-313.

Ewers, B., Trolle, E., Jacobsen, S.S., Vististen, D., Almdal, T.P., Vilsboll, T., Bruun, J.M. 2019. Dietary habits and adherence to dietary recommendations in patients with type 1 and type 2 diabetes compared with the general population in Denmark. Nutrition, 61, 4955 .

Hipsley, E.H. 1953. Dietary "fibre" and pregnancy toxaemia. British Medical Journal, 2(4833), 420-422

Hollmann, J., Themeier, H., Neese, U., Lindhauer, M.G. 2013. Dietary fibre fractions in cereal foods measured by a new integrated AOAC method. Food Chemistry, 140, 586589.

ICC Standard No 105/2. 2003. in ICC Standard methods of the International Association for Cereal Science and Technology, ICC, Vienna, Austria.

ISO 5530-1. 2013. Wheat flour. Physical characteristics of doughs, Part 1: Determination of water absorption and rheological properties using a farinograph.

ISO 5530-2. 2013. Wheat flour. Physical characteristics of doughs, Part 2: Determination of rheological properties using an extensograph.

Jayaram, V. B., Cuyvers, S., Lagrain, B., Verstrepen, K.J., Delcour, J.A., Courtin, C.M. 2013. Mapping of Saccharomyces cerevisiae metabolites in fermenting wheat straightdough reveals succinic acid as pH-determining factor. Food Chemistry, 136, 301-308.

Jeddou, K. B., Bouaziz, F., Zouari-Ellouzi, S., Chaari, F., Ellouz-Chaabouni, S., EllouzGhorbel, R., Nouri-Ellouz, O. 2017. Improvement of texture and sensory properties of cakes by addition of potato peel powder with high level of dietary fiber and protein. Food Chemistry, 217, 668-677.

Kaczmarczyk, M.M., Miller, M.J., Freund, G.G. 2012. The health benefits of dietary fiber: Beyond the usual suspects of type 2 diabetes mellitus, cardiovascular disease and colon cancer. Metabolism Clinical and Experimental, 61, 1058-1066.

Ktenioudaki, A., Butler, F., Gonzales-Barron, U., Mc Carthy, U., Gallagher, E. 2009. Monitoring the dynamic density of wheat dough during fermentation. Journal of Food Engineering, 95, 332-338.

López-Vargas, J.H., Fernández-López, J., Pérez-Álvarez, J.A., Viuda-Martos, M. 2013. Chemical, physico-chemical, technological, antibacterial and antioxidant properties of dietary fiber powder obtained from yellow passion fruit (Passiflora edulis var. flavicarpa) co-products. Food Research International, 51, 756-763. 
Madi-Azegagh, K., Yahiaoui, Y., Boudrahem, F., Aissani-Benissad, F., Vial, C., Audonnet, F., Favier, L. 2018. Applied of central composite design for the optimization of removal yield of the ketoprofen (KTP) using electrocoagulation process. Separation Science and Technology, DOI: 10.1080/01496395.2018.1556298.

Makki, K., Deehan, E.C., Walter, J., Backhed, F. 2018. The impact of dietary fiber on gut microbiota in host health and disease. Cell Host \& Microbe, 23(6), 705-715.

Martínez, R., Torres, P., Meneses, M.A., Figueroa, J.G., Pérez-Álvarez, J.A., ViudaMartos, M. 2012. Chemical, technological and in vitro antioxidant properties of mango, guava, pineapple and passion fruit dietary fibre concentrate. Food Chemistry, 135, 1520-1526.

McCleary, B.V. 2007. An integrated procedure for the measurement of total dietary fibre (including resistant starch), non-digestible oligosaccharides and available carbohydrates. Analytical and Bioanalytical Chemistry, 389, 291-308.

McRae, M.P. 2017. Dietary fiber is beneficial for the prevention of cardiovascular disease: An umbrella review of meta-analyses. Journal of Chiropractic Medicine, 16(4), 289299.

Montesinos-Herrero, C., Cottell, D.C., O’Riordan, E.D., O’Sullivan, M. 2006. Partial replacement of fat by functional fibre in imitation cheese: Effects on rheology and microstructure. International Dairy Journal, 16, 910-919.

Noronha, N., O’Riordan, E.D., O’Sullivan, M. 2007. Replacement of fat with functional fibre in imitation cheese. International Dairy Journal, 17, 1073-1082.

O'Shea, N., Arendt, E.K., Gallagher, E. 2012. Dietary fibre and phytochemical characteristics of fruit and vegetable by-products and their recent applications as novel ingredients in food products. Innovative Food Science \& Emerging Technologies, 16, 110 .

Pastell, H., Putkonen, T., Rita, H. 2019. Dietary fibre in legumes, seeds, vegetables, fruits and mushrooms: Comparing traditional and semi-automated filtration techniques. Journal of Food Composition and Analysis, 75, 1-7.

Popa (Ungureanu), C., Bahrim, G., Favier, L., Tanase, C. 2015a. Increase of the Trametes Versicolor efficiency in bioremediation process for diclofenac biodegradation in aquatic environments. Annals of the University Dunarea de Jos of Galati, Fascicle VI - Food Technology, 39(1), 25-35.

Popa (Ungureanu), C., Favier, L., Bahrim, G., Amrane, A. 2015b. Response surface optimization of experimental conditions for carbamazepine biodegradation by Streptomyces MIUG 4.89. New Biotechnology, 32(3), 347-357.

Rohan, T.E., Howe, G.R., Friedenreich, C.M., Jain, M., Miller, A.B. 1992. Dietary fiber, vitamins A, C, E and risk of breast cancer: a cohort study. Cancer Causes and Control, 4, 29-37.

Segundo, C., Roman, L., Gomez, M., Martinez, M. M. 2017. Mechanically fractionated flour isolated from green bananas (M. cavendishii var. nanica) as a tool to increase the dietary fiber and phytochemical bioactivity of layer and sponge cakes. Food Chemistry, 219, 240248.

Shanmugam, S., Monis, S.A., Roy, N., Sangamithra, S.D., John, S.G. 2017. Effect of antioxidants and dietary fiber from apple and strawberries on value addition into mutton patties. The Annals of the University Dunarea de Jos of Galati, 41(1), 95-105. 
Shrivastava, C., Chakraborty, S. 2018. Bread from wheat flour partially replaced by fermented chickpea flour: Optimizing the formulation and fuzzy analysis of sensory data. LWT-Food Science and Technology, 90, 215-223.

Simion, A.I., Grigoraş, C.G., Moroi, A., Vartolomei, N. 2015. Mathematical modelling of pasta dough dynamic viscosity, thermal conductivity and diffusivity. The Annals of the University Dunarea de Jos of Galati, Fascicle VI - Food Technology, 39(1), 81-92.

Simion, A.I., Grigoraș, C.G., Favier, L., Moroi, A.M., Kadmi, Y., Bahrim, G.E. 2017. Successful fodder yeast production from agro-industrial by products through a statistical optimization approach. Romanian Biotechnological Letters, 22(3), 12671-12679.

Soleimani Pour-Damanab, A.R., Jafary, A., Rafiee, Sh. 2011. Monitoring the dynamic density of dough during fermentation using digital imaging method. Journal of Food Engineering, 107, 8-13.

Vasantha Rupasinghe, H.P., Wang, L., Huber, G.M., Pitts, N.L. 2008. Effect of baking on dietary fibre and phenolics of muffins incorporated with apple skin powder. Food Chemistry, 107, 1217-1224.

Wenzel de Menezes, E., Bistriche Giuntini, E., Tanasov Dan, M.C., Hoffmann Sarda, F.A., Lajolo, F.M. 2011. Codex dietary fibre definition - Justification for inclusion of carbohydrates from 3 to 9 degrees of polymerization. Food Chemistry, 124, 411-421.

Xu, H., Ding, Y., Xin, X., Wang, W., Zhang, D. 2018. Dietary fiber intake is associated with a reduced risk of ovarian cancer: a dose-response meta-analysis. Nutrition Research, 57, 1-11. 